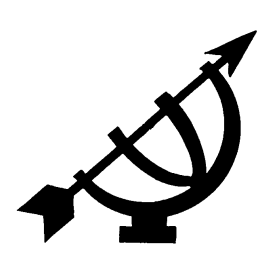

\title{
Concerns about the future of creation order
}

\author{
A.H. Verhoef \\ School of Philosophy \\ Potchefstroom Campus \\ North-West University \\ POTCHEFSTROOM \\ E-mail: anne.verhoef@nwu.ac.za
}

\section{Abstract \\ Concerns about the future of creation order}

The theological background to the notion of the law of nature/ creation order is indispensable to the reformational tradition, which recognises that these laws are the Creator's will, and therefore holds a "necessity" view of these laws. There has, however, been a longstanding debate about the nature of law within the reformational tradition, where its origin and its status as boundary between God and creation have been questioned. In this article I will investigate how Trinitarian theology, specifically that of Robert $W$. Jenson, relates to process philosophy and theology, and how together they create some theological concerns about the future of creation order. Some of the concerns include the following: that the necessity of order is questioned (the disappearance of a Creator who wills these laws); that order is temporal and in constant change; and that the boundary between God and creation is weakened. I will raise some objections to these aspects, but will also highlight some questions the reformational tradition has to answer in terms of its understanding of the immanence of God and of the implicated theological basis for the creation order. These questions are of the utmost importance for the understanding of the future of creation order.

\section{Opsomming}

\section{Besorgdheid oor die toekoms van skeppingsorde}

Die teologiese agtergrond van die idee van 'n skeppingsorde is onontbeerlik vir die reformatoriese tradisie. Volgens hierdie tradisie is die natuurwette die Skepper se wil en daarom word 
hierdie orde as noodsaaklik beskou. 'n Voortslepende debat binne die reformatoriese tradisie bestaan egter lank reeds ten opsigte van die aard van die skeppingsordening, waarvolgens die oorsprong en status daarvan as skeiding tussen God en die skepping bevraagteken word. Ek gaan in hierdie artikel ondersoek instel na die Trinitariese teologie, spesifiek hoe dié van Robert W. Jenson verband hou met prosesfilosofie en -teologie, asook hoe dit gesamentlik sekere teologiese bekommernise oor die toekoms van 'n skeppingsorde laat ontstaan. Sommige van hierdie kwessies sluit in dat die noodsaaklikheid van 'n skeppingsorde bevraagteken word (die verdwyning van 'n Skepper wat hierdie ordeninge wil); dat orde tydelik is en gedurig verander; en dat die grens tussen God en skepping vervaag. Ek sal sekere besware oor hierdie kwessies opper, maar ek sal ook sekere vrae uitlig wat die reformatoriese tradisie moet beantwoord in terme van hulle begrip van die immanensie van God en van die geïmpliseerde teologiese grondslag van die skeppingsorde. Hierdie vrae is van die uiterste belang vir insig oor die toekoms van 'n skeppingsorde.

\section{Introduction}

The question posed in this article concerns the future of creation order. ${ }^{1}$ Does creation order have a future? To answer this, I will first look at the theological basis of creation order. My hypothesis is that the future of creation order might come under significant threat if its theological basis is undermined. The necessity of creation order is thus a notion that I develop in part one, while in part two I connect the opposite of this notion, namely probability, to process philosophy and theology. In part three I draw a link between process philosophy

1 The concept creation order will be used to emphasise that God willed this order (laws of nature) as Creator. In some instances "laws of nature" will be used to emphasise the "natural" aspects of these laws, but in most cases the terms will be used interchangeably.

Creation order is thus understood here primarily as laws of nature and not in the broader sense as defined by reformational philosophy - reformational philosophy never restricted creation order to natural laws, because it acknowledges also ontic normativity as part of the creation order. Dooyeweerd has for example an encompassing idea of the creation order, including both natural laws and the creational principles guiding human activities - in a functional and a typical sense.

This article will not focus on this reformational philosophical view of creation order per se, but the implications might be relevant for this tradition in the sense that it also distinguishes God from creation. Due to space constraints, further analysis of this point will have to wait for a follow-up article. 
and Trinitarian theology in an effort to reconsider the value of process philosophy in thinking about creation order. This is necessary because in reformational theology, process theology has been much criticised and its legitimate aspects are perhaps not emphasised enough. Lastly, I will indicate the challenges all of this has for the future of creation order. My conclusion is in more than one sense an open one.

\section{The theological basis for creation order}

Without a proper basis any theory is suspect, and it is therefore of the utmost importance to investigate the theological basis of creation order. In the reformational tradition ${ }^{2}$ the notion of the laws of nature as something God-given is indispensable. In this tradition God is understood as the Creator who has created this order and who wills these laws. When for example, Jacob Klapwijk in his book Purpose in the living world? Creation and emergent evolution (2008) asks if there is such a thing as divine creation order, he says it cannot be answered by science. He says the belief in a creation order is something a believing person (a Christian in this case) could be reassured of by reading Psalm 19. Klapwijk (2008:237) adds that

... the Christian church has confessed, through the ages, its faith in God as the almighty creator of heaven and earth, who upholds His creation, and who also makes life livable by subjecting it to His ordinances.

The philosopher John Polkinghorne follows the same line of thought as Klapwijk when he states that science does not have sufficient ability to explain the nature of the order that we find in the physical world. He says:

The rationally transparent and beautiful principles of order already discerned as shaping cosmic process have a character that seems to call for further explanatory insight lying beyond that which science on its own can provide. (Polkinghorne, 2008:192.)

2 "Reformational tradition" here includes both the philosophical and the theological traditions as far as both posit creation as something other than God, and thus maintain a distinction between Creator and creation. This article's aim is therefore not to engage primarily with the tradition of reformational philosophy as initiated by Dooyeweerd, but with the reformational tradition in the broader sense. 
He further argues that to treat the structure of the universe as "merely a happy accident" would seem to be both implausible and intellectually supine, and therefore he also chooses an explanation that refers to God and religion. Polkinghorne (2008:192) concludes that "Religious insights ... offer a more profound context within which to consider these matters". He adds that a religious understanding of the creation order also allows for concepts like value and purpose to be used when talking about the universe - something which natural science often does not have room for to acknowledge.

The history of the idea of the laws of nature shows that the concept of laws of nature was initially based on theological assumptions, but it has increasingly been maintained without such assumptions. Peter Harrison, in his book The development of the concept of the Laws of Nature (2008), describes that the laws of nature (the remarkable features of the physical universe to conform to mathematical laws) are not simply descriptions of regularities, but "rather they dictate how things must be ... some kind of natural necessity" (Harrison, 2008:13). He explains that the idea of a world governed by laws of nature, as a result of God's direct involvement in the operations of nature, developed since the seventeenth century. The laws are mathematical because "God was conceptualized as the divine mathematician" and the laws were a necessity because they "arise out of the fact that God's will is immutable, and hence the laws that he wills into effect are unchangeable" (Harrison, 2008:28).

The answer to the question as to why there are laws of nature at all therefore involved a theological commitment. According to Harrison, things changed in the nineteenth century when "laws of nature came to be regarded not as laws imposed on nature by God, but literally as laws of nature itself" (Harrison, 2008:28). These laws were now referred to as "laws of science" or "scientific laws", which indicate the elevated status of science and the corresponding decline in the emphasis on God's role in the instantiation of natural laws. In the twentieth century the idea of laws of nature was thus separated from its original theistic justifications and given a wider application, but it has also lost its deterministic and theistic connotations. The implication of this changed application for contemporary philosophy is one of division and confusion about the laws of nature: some assert that they capture some necessary state of affairs; others see them as significantly mind-dependent; and yet others find the problems associated with these views insurmountable and assert that 
there is simply no such thing as laws of nature. ${ }^{3}$ Harrison's conclusion is that this confusion resulted from the fact that the idea (of laws of nature) has been separated from its theological commitment.

Philip Clayton, in his Contemporary philosophical concepts of law and nature: the quest for broad explanatory consonance (2008) links up with Harrison's argument about the need for laws of nature to be understood in terms of religious beliefs. He asks the question if it could be that the laws of nature have not only a physical, but also a theological story to tell. He adds that the status of natural laws is a topic of vital interest to science-religion debates and he shows the comparisons between them in this regard: where science speaks of nature, theologians speaks of creation; science presupposes the fundamental constants as given, while theological doctrines hold that lawlike regularities in the natural world depend on the ongoing divine will. Clayton says that the theological traditions include at least three major positions on the topic of natural law, namely laws as eternal necessities, laws as necessities "imposed upon the world by divine choice, which become binding once God has decided upon them"; and laws as patterns that humans discern which "are significant but nonetheless open to change as God acts in novel ways within the world" (Clayton, 2008:39). According to the first two views, God has established certain laws right at the moment of creation, but the third view holds that God is not presently bound by any decisions. 4 The implication of this third view is that there is some order in the natural world, but this order does not constrain future divine action in any significant way - God is completely free to change them. ${ }^{5}$ Clayton (2008:40) states that according to this third view

... scientists may well speak of 'laws', but all that term can really mean is that we discern regularities in the natural order at the

3 Armstrong is representative of this view. He holds that laws of nature describe a relation between two universals and says for example: “... to have drawn this consequence is already to have produced a good reason for denying that the laws of nature are strongly necessary. For I maintain that universals are just as much contingent beings as particulars are." (Armstrong, 1983:164.)

4 This view goes back to Ockham's nominalism and his idea of God's potestas Dei absoluta.

5 The position assumed by Calvin was that God is not subject to his laws for creation, but it is also not arbitrary, for in his providential plan He holds Himself to what He ordained: Deus legibus solutes est, sed non exlex. 
present ... New 'laws' emerge when God changes God's patterns of activity.

A distinction is thus made between the "regularity" and "necessity" views of the laws of nature. It is important (at least for the argument of this article) to find clarity regarding this distinction.

The regularity view accepts a picture of natural laws freed from any necessity, and free from any metaphysics. David Hume ${ }^{6}$ argues, for example, that natural laws are nothing more than the description of patterns that have arisen in the past and will (as far as we know) continue into the future. Therefore there is no necessity that links a cause to its effect - nature does not know cause and effect. We may sometimes feel there is a relation of necessity between two things, but according to Hume it is merely a psychological fact about us. The regularity theory suffers from a serious problem, as it appears to make it impossible for laws to actually explain anything because there is no metaphysical link to the generalisation. On the regularity view, what exist ultimately are individuals (Clayton, 2008:48). In contrast, the necessity view discerns stronger connections with the natural world and states that "natural laws seem to have a normative force: they tell us not merely how things happen to have been so far, but how things must be" (Clayton, 2008:44). The necessity view seeks to ground the necessities expressed by physical laws in something deeper than individuals, in something more metaphysical. For example, laws like the law of gravity holds necessarily because it is metaphysically true that a large number of events share the same set of core properties, they are instances of one general law. These patterns might be established by a divinely established law, or they can, for example, form part of the world that consists "entirely of relations" (Clayton, 2008:48). For Clayton, the regularity view is misguided on this point because it treats the objects of our experience as separate objects, when they are in fact part of more fundamental forces. He argues that the necessity view is the more correct view to have. In his argument he refers to Ayer, who notes that "our present use of the expression 'laws of nature' carries traces of the conception of Nature as subject to command" (Ayer, 1998: 809). In other words "laws of nature" does not only include the idea of pattern, but the way things must be. Clayton sees this association

6 David Hume is the classic exponent of this regularity view and the greatest challenge to any metaphysical component in natural laws is the Humean objection - see in this regard Hume's Enquiries concerning the human understanding and concerning the principles of morals (1902). 
as an intrinsic one and says that "science can only explain phenomena when it recognizes (rather than creates) deeper connections that underlie our empirical observations and make them what they are" (Clayton, 2008:50). Thus, for Clayton laws of nature are necessities in that they express intrinsic connections within nature which we do not create but perceive within nature itself. He chooses this view above the regularities view, as part of his quest for broad explanatory consonance between one's religious standpoint, the scientific data, and their implications. ${ }^{7}$ Clayton's conclusion is that the theist who accepts the necessity view of natural law (which he defends) can view these necessary connections as established by God. He says:

If there is a Creator God, as theists maintain, and there are invariant lawlike connections in the natural world, then it is much more natural to assume that the nature of the Creator is reflected in the nature of the created world. (Clayton, 2008:55.)

Clayton's conclusion brings me back to the fact that the concept of creation order or laws of nature reflects confidence and trust in God, as the One who wills and maintains these laws. Furthermore, the reformational tradition, which holds the view that the Creator is willing these laws, therefore, holds a necessity view of these laws. According to Clayton's and Harrison's arguments this is the proper way to understand them. 8 There has, however, been a longstanding debate over the nature of law within this tradition, where its origin and its status as boundary between God and creation have been questioned. Although both scholastic metaphysics and Deism have been rejected within the reformational tradition, the question still remains how the immanence of God should be understood, especially in relation to the theological basis of the nature of creation order. 9 On this aspect I will now focus my argument.

$7 \quad$ Space prevents me from explaining the whole argument of Clayton here, but in short he uses the criteria of systematicity and internal coherence to evaluate the different proposals on four different philosophical levels.

The unstated implication of Harrison's argument seems to be that if the necessity view of laws of nature is not accepted, the whole idea of such a concept might be given up because of the confusion and division it then creates.

9 It should, however, be kept in mind that within the reformational philosophical tradition creation order is something ontically given and therefore it cannot have a "theological basis". See in this regard Dooyeweerd's $A$ new critique of theoretical thought (1958) and Strauss's Philosophy: discipline of the disciplines (2009). 


\section{Creation order and process philosophy/theology}

Within the reformational tradition the laws of nature are seen as the creation order, something willed by God and something that is a necessity. The underlying assumption in this understanding is that God is the Creator, and for Him to create is to bring something into existence which is separate from Himself - in other words everything other than God Himself is creation. 10 However, creation is not to be understood solely in terms of what happened initially. This would neglect the continuing nature of God's work of creation and lead to the heresy of deistic thinking. Deism has been rejected within the reformational tradition, and creation is rather understood as God's continuing creation in the sense that He maintains his creation and that He gives purpose to it. ${ }^{11}$ Exactly how God's immanence should be understood within this picture (of Creator fundamentally distinct from his creation, and with laws of nature as necessities) is something theologians disagree about.

Fraser Watts, in his Concepts of law and probability in theology and science (2008) says theologians are pulled in conflicting directions about the laws of nature. On the one hand they want to emphasise the lawfulness of nature as reflection of God's faithfulness, and on the other hand they want to emphasise the openness of creation as reflecting God's continuing initiative. Some will say "God does not play dice" (like Einstein) and that God set the laws of nature to be unchangeable and necessary. The problem then is how God can interact in the world without breaking or changing these laws. (If $\mathrm{He}$ only maintains them He might be seen as Deistic.) Therefore, others would maintain that there are other possibilities for God to act in the world (for example to respond to prayer) than just maintaining the laws of nature. They will probably accept "a softer view of the laws of nature" (Watts, 2008:2), which can make it easier to see how divine action can be reconciled with laws of nature without those laws being violated. This "softer view" seems, however, to be a move away from the necessity view of laws of nature to the regularity view, but this would be in conflict with the reformational tradition's view about the laws of nature. An alternative should therefore

10 The theologian Karl Barth says: "God creates and therefore gives reality to another alongside and outside himself ..." (1964:41). This is in line with the reformational theologians like Luther and Calvin.

11 Klapwijk says "the creation order has a conserving and a prophetic content. It speaks of God's purpose from of old, and of its intentions for the present and the future" (2008:237, footnote 4). 
be investigated and in this endeavour Watts's distinction between law and probability is helpful.

Watts (2008:2) states that the lawfulness of nature came to have overtones of determinism during the Enlightenment. Laws of nature may thus be seen as closely related to both determinism and necessity. Determinism has probably been more prominent in philosophy of science, and necessity more in philosophical theology. Watts discusses chance, unpredictability and probability as opposite terms to lawfulness, necessity and determinism. He shows that law and probability may not be mutually exclusive, but that they in fact have a conceptual interconnectedness between them (one is parasitic on the other and cannot be defined without the other). The concept of probability is, for Watts, much closer to lawfulness than is either chance or unpredictability. He explains:

It is a reasonable extension of the concept of the lawfulness of the natural world to include probabilistic laws as well as absolute ones. The key difference is perhaps that predictions from absolute laws are necessary, whereas predictions from probabilistic laws are contingent. Probability combines an element of predictability with an element of openness. (Watts, 2008:5.)

Laws of nature therefore include both absolute laws (with necessary predictions) and probabilistic laws (with contingent predictions). These probabilistic laws allow openness (as opposed to predictability), "emergence" (as chaos theory has shown order can arise "at the edge of chaos") and a degree of freedom (something that can emerge at one level from determinism at a lower level). Probability thus opens up the possibility within our understanding of laws of nature for divine action and a better understanding of God's immanence. The implication is that the universe is not to be understood with only "fixed elements of general structure; but it is an open and developing system - so it is open at many points to creative change" (Ward, 2008a:37).

We can accordingly say that God's primal action of creation is the positing of a universe with general structural necessities (laws of nature); but this does not exclude further divine actions, especially not acts at the points of the contingent process where the open universe invites it. Keith Ward, in his book Divine action: examining God's role in an open and emergent universe (2008a) declares that the

... universe is open at many points to the influence of Divine and human choices ... within parameters of necessity ... in ways 
which affect the future, determining it to be in a state which might otherwise have been different (Ward, 2008a:74).

Divine action (or immanence) understood in this way, is very much in accord with the way process philosophy understands God. Alfred North Whitehead (who can be regarded as the father of process philosophy), for example, views God as "a constantly new creator, bringing new things into being, in a time that flies toward an open future but a future that is always governed by having its ultimate goal in God" (Ward, 2008b:251). God has as a result a very creative role and acts not only as the source of cosmic order. In Whitehead's process philosophy the world

... never reaches completion and neither does God, for both are in the grip of the ultimate ground, creativity. God is not a being hypostatized before creation; rather, divine reality is always in process with creation. (Dorrien, 2008:318.) ${ }^{12}$

In process thought the metaphysical claim is consequently that becoming is more elemental than being, because reality is fundamentally temporal and creative. Therefore, in Whitehead's philosophy, finite persons are societies of small events or "actual occasions", each one existing for a moment, integrating its direct past and projecting creatively into its immediate future. God is then the "Ideal Goal, causally influencing but not determining things toward their ultimate goal of union with the Divine" (Ward, 2008b:252). For Whitehead, God experiences all the feelings of finite beings and includes them in the Divine Being. Process theologians describe this by "speaking of all finite experiences as 'included in' God. Thus Charles Hartshorne says that God is 'world-inclusive, having all things as constituents'." (Ward, 2008a:25.) This is why process theologians are generally regarded as panentheists.

To summarise and to link up with my argument again, we must say that within process philosophy (and theology) God is seen as the creative counterpart from the inception of the development process

12 According to Cobb and Griffin (1976:59), "[p]rocess theology understands God precisely as the basic source of unrest in the universe". This shows the willingness of process thought to embrace tension and a degree of conflict. William Hasker (2005:192) says:

For process theism, the ultimate divine aim is for enjoyment - by the creatures, and by God himself. Enjoyment requires both order and novelty. Without order, chaos reigns and significant enjoyment is impossible, but without the constant infusion of novelty, order stagnates and enjoyment remains at a stage of unnecessary triviality. 
of creation. This view has the implication of a pantheistic view of God, one in which He participates in reality, as being part of that reality. Such an understanding of God's immanence has the implication of creation order (laws of nature) being temporal and inevitably being in constant change (or has at least the ability to be). The question that may follow is what the status of creation order is, and whether it is still meaningful to speak about laws of nature, especially as necessities. Before these questions are discussed it must be mentioned that process philosophy and theology has been criticised by reformational theology on numerous points. Some of the critique includes that it is unbiblical and other that God cannot be understood in a panentheistic manner. Although much of the critique might be fair from a reformational theological view, it should be noted that recently there have been new developments, especially in Trinitarian theology that supports the main thrust of process theology from a completely different and much more biblical angle. I will discuss this development next, focusing on only one representative example, namely the Trinitarian theology of Robert Jenson.

\section{Process philosophy/theology and the Trinitarian theology of Robert Jenson 13}

Robert Jenson is well-known as a significant and prolific writer on Trinitarian theology and eschatology. Jenson is an American Lutheran theologian who for more than 40 years, has written extensively and very creatively about the Trinity, time and eternity. ${ }^{14}$ Some of his main works as a Trinitarian theologian include his dogmatic works (Jenson, 1997; 1999;15 1969 and 1963).

Jenson's theology is to a great extent a reaction to the Hellenistic influences on the early church's theology, especially in regard to concepts like the impassibility and timelessness of God. ${ }^{16}$ The very

13 This discussion of Jenson's theology rests on previous work on this theologian (cf. Verhoef, 2011a and 2011b).

14 Although Jenson is sometimes described as an American theologian, he is wellknown and respected internationally as a theologian. In Gunton's book (2000) on Jenson, theologians from all over the world and from many different denominations contributed essays of appreciation and dialogue with Jenson's theology.

15 The theologian Carl Braaten says these books are undoubtedly the crowning fulfilment of Jenson's career. 
definition of God's eternity as "timeless" is something Jenson regards as unbiblical and incompatible with the story of creation and redemption. 17 God is not timeless, but God is "identified by specific temporal actions and is known within certain temporal communities by personal names and identifying descriptions thereby provided" (Jenson, 1997:44). God is not timeless, but lively, active, an event. Jenson follows Gregory of Nyssa's thoughts and says "God ... refers to the mutual action of the identities' divine 'energies', to the perichoretic life" (Jenson, 1997:214) and "This being of God is not a something, however rarefied or immaterial, but a going-on, a sequentially palpable event, like a kiss or a train wreck" (Jenson, 1997:214). This "temporality" of God is described by Jenson as God's "temporal infinity". Jenson prefer to use the term infinity (limitlessness) instead of timelessness about God, because God is not infinite in the sense that he "extends indefinitely, but because no temporal activity can keep up with the activity that he is" (Jenson, 1997:216). God is infinite not by having no boundaries, but by overcoming the boundaries. Therefore, Jenson asserts that God's being should be described as temporal infinity. For Jenson this term demonstrates God's self-liberation from temporal contingencies, without extracting Him from history.

According to Jenson, this temporal infinity or "timefullness" of God is not just something ascribed to God, but it is part of the being of God. It is central to the relationships within the Trinity - it defines God. For Jenson there is a clear connection between the poles of time and the mutual triune roles of Father, Son, and Spirit. According to him, the "Father is the 'whence' of God's life; the Spirit is the 'whither' of God's life; and ... the Son is that life's specious present" (Jenson,

According to Jenson, the Greeks, in an effort toward security of existence over against time's fleetingness, defined eternity in terms of timelessness. Since humanity cannot embrace our past, present, and future giving us the coherence of life that we naturally desire, the ancient Greeks projected that ability onto God and therefore defined deity in terms of persistence or immutability. Jenson asserts that while the early church did not simply assimilate Hellenism into its theology, it nonetheless failed to rid itself of certain debilitating features, the pinnacle of which is the notion of divine timelessness.

17 Pannenberg (2000:49) says:

Jenson is surely right in contending that the God of the Bible is identified by temporal events, and indeed by a history of such events. $\mathrm{He}$ boldly integrates this insight with his Trinitarian theology by conceiving of the biblical narrative as 'the final truth of God's own reality' in the mutual relations of God the Father, His incarnate Son, and the eschatological accomplishment of their communion by the Spirit. 
1997:218-219). Thus, for Jenson God possesses a past, present, and future in Himself; not only as pure duration (as Karl Barth understood it, with no conflict but only peace between source, movement and goal), but as a temporal infinity. 18 Jenson says God

... is temporally infinite because 'source' and 'goal' are present and asymmetrical in him, because he is primally future to himself and only thereupon past and present for himself (Jenson, 1997:217).

The climax of Jenson's theology is that the end will be theosis. Jenson says: "God and only God is the creature's future. God the Spirit is God's own future and so draws to and into the triune converse those for whom the Trinity makes room" (Jenson, 1999: 26). ${ }^{19}$ We can thus say that the unity of Jenson's theology lies in the fact that the Trinity is temporally defined in relation to the claim that God is in fact the mutual life and action of the three persons, Father, Son and Spirit, as they move towards the future. This relationship between God and time is central to Jenson's Trinitarian thought. However, the relationship between time and space - and consequently our space in God - needs to be clarified if we want to understand what Jenson means by a Trinity that "makes room" for us.

As we have seen, for Jenson time is no longer what separates God and the world, instead time is defined as common ground. But, while time is something outside us, Jenson states that time is inside the divine subjective centre. Jenson follows Augustine's description that time is

18 Jenson agrees with the pure duration of Barth in the sense that "nothing in God recedes into the past or approaches from the future" but he differs from Barth when he adds: "But the difference is also absolute: the arrow of God's eternity, like the arrow of casual time, does not reverse itself. Whence and whither in God are not like right or left or up and down on a map, but are like before and after in a narrative." (Jenson, 1997:218.)

19 Pannenberg says that it is at this point where Jenson's systematic unity of his theology is found:

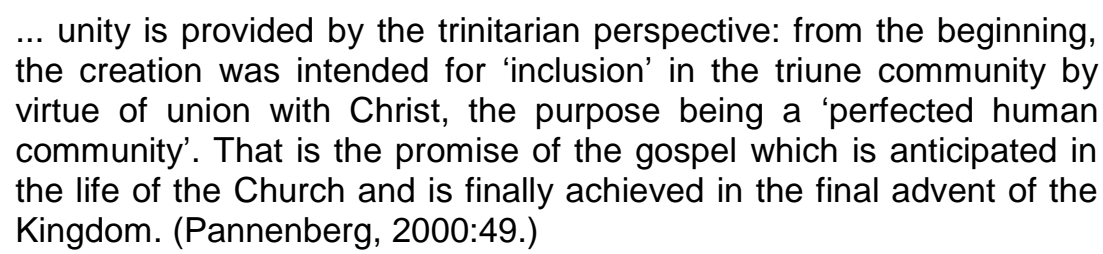


... the 'distention' of a personal reality ... That is: the 'stretching out' that makes time is an extension not of finite consciousness

but of an infinite enveloping consciousness (Jenson, 1999:34).

So, it is in this "enveloping consciousness" of God that time is internal. So it is not outside God, but inside Him, asymmetrical in his perichoresis that time exists.

In addition, for Jenson it is "exactly the divine internality of time that is the possibility of creaturehood at all" (Cumin, 2007:173). Here we find the strong relationship of time and space when Jenson says:

... for God to create is for him to make accommodation in his triune life for other persons and things than the three whose mutual life he is. In himself, he opens room, and that act is the event of creation ... We call this accommodation in the triune life 'time'... creation is above all God's taking time for us (Jenson, 1999:25).

Therefore, for Jenson, created time is accommodation in God's eternity for those other than God and consequently we can speak about God's roominess (Jenson, 1999:25). The implication of this is that everything appears to exist in God and that there is no other possible way for things to exist. For this reason Jenson is often accused of panentheism and even "pan-en-trinitarianism",20 and this in turn leads to questions about God's aseity or self-sufficiency. The problem is that, in Jenson's words (2006:33):

Those on the one side of the argument accuse those on the other of so identifying God with history among us as to make him dependent on us. Those of the latter party accuse those of the former of continuing so to construe eternity by categories alien to the biblical account of God - for example, by timelessness.

To summarise: the Trinitarian theology of Jenson places a strong emphasis on God's "temporality" and Jenson asserts that God is not timeless, but "timeful". This timefulness (or temporal infinity) is not only an attribute of God, but forms part of his identity as the Trinity. For Jenson, this is the most coherent way of understanding God in terms of his biblical revelation. In addition, this understanding of God

20 Mark Mattes (2000:484) says for example: “The logic of Jenson's view of God is led by a conceptual commitment to a 'pan-en-trinitarianism' in which all histories are called to their fulfilment by the very life of the triune God finding itself in, with, and under these histories." 
and time has implications for the understanding of God's space, and here lies another strong link with process theology. God is therefore connected to creation, not only in his "temporality", but also in his accommodation of creation in Him. From a different (and much more biblical) angle we hence arrive at more or less the same conclusion about God's relationship to the world (and creation order) as did process philosophy and theology.

\section{The challenges of process theology and Trinitarian theology to the future of creation order}

The Trinitarian theology, especially that of Jenson, stands therefore in relation to process philosophy and theology and together it creates some serious theological concerns about the future of creation order. Before I highlight some of these I want to recap on my argument so far. The first part states the importance of the theological basis for creation order. An important aspect of the theological basis is that laws of nature are seen as necessities: they are normative (they dictate how things should be). If the laws of nature were understood only as regularities they might be seen only as psychological processes (merely human projection), and their theological basis would thus be questioned. These questions may include: If God really created the laws of nature, are they still laws or are they too changeable to be called that? Is God part of these laws, part of nature? Is He Himself subject to its laws? These are all questions that have on the one hand serious implications for our view of God and creation order, but on the other hand, create questions about God's immanence and creation's determinism.

Part two investigates whether the necessity view (of laws of nature) allows some room for God's immanence (or divine action) and found some possibilities in Watts's explanation of probability. Watts states that probability is part of necessity, and that it combines an element of predictability with an element of openness. This leads to an understanding of the universe as open, emergent and free, in contrast to the closed, fixed system as the necessity view would have it. This outcome again sounds very much like the regularities view of laws of nature, but on the other hand it connects very strongly with concepts very familiar in process philosophy and theology. The pantheistic and (sometimes) unbiblical view of God in process philosophy/theology makes it, however, a dead end for the reformational tradition. Therefore, part three focuses on how Trinitarian theology (especially that of Robert Jenson) gave more biblical grounds to process philosophy and theology (which might include "pan-en- 
trinitarianism"). Regarding who God is, the notion of process theology might thus be more acceptable, and makes it worthwhile to investigate more seriously what the process thought perspective is on laws of nature.21

This leads us to the question of what the status of laws of nature consequently is. Can we still speak of creation order as something intelligible, and is there a theological basis to it in the simple sense that God willed and maintains it (as necessity)? We have seen that if the regularities view, or the process view (of openness, emergence of the universe) regarding the laws of nature is accepted, we are faced with similar difficulties or concerns. Among these concerns are the question regarding the necessity of order (as a consequence of the disappearance of a Creator who is willing these laws because it is all mind-dependent); that order is temporal and in constant change (as part of the openness and emergence of creation); and that the boundary between God and creation is weakened (with the inclination to panentheism). To overcome these concerns an option may be to stick to the necessity view of creation order, as the reformational tradition did, but this would not sufficiently address the problem of God's immanence and of emergence in nature. A better option will be to accept that necessities include probabilities (as Watts suggests). This may have the implication of moving to the regularity view, but "lawfulness probably needs to exist in some sense in both nature and the human mind before the two can be brought together" (Watts, 2008:3). Understood in this way, laws of nature do not have to implicate a huge distance between God and creation, but rather that God is dynamical and actively involved in this open and emerging universe - as process philosophy and Jenson suggest. This does not necessarily mean that God is subject to the laws of nature in the sense that $\mathrm{He}$ is not God anymore (regarding his aseity), but rather that God's normal actions

... work within the structure of intelligible regularity, limited openness, continuous teleological development, and the interconnectedness of objects in a cosmic totality (Ward, 2008b: 252).

21 The importance of the necessary link between process theology and Trinitarian theology is highlighted by Pannenberg (2007:33) when he says about Trinitarian theology: "Theology that is distinctively Christian will attribute the creation to the trinitarian God - Father, Son, and Holy Spirit. In Christian theology, there is no room for a pre-trinitarian monotheism of the one God." This link is what I tried to establish in the third part of this article. 
This allows for a much more dynamic understanding of God's immanence.

\section{Conclusion}

To answer the question investigated by this article regarding the future of creation order, I will say that its future is open. It is open in the sense that we are all living in an open and emerging universe (with the implication of changing laws), but also open in the sense that the future is also open to God (as open theists assert). ${ }^{22}$ Laws of nature, or creation order, should thus be understood as much more open than it has been traditionally understood in the reformational tradition. This has implications for our view of God as a much more dynamic, active and temporal God (in line with Jenson), but it does not necessarily need to include a panentheistic view. ${ }^{23}$ There are obviously many possible objections to arise from within the Trinitarian and reformational theology on this view of creation order, as well as on some aspects of Jenson's theology (and process theology). However, the immanence of God may potentially be diminished by such objections. My answer remains consequently a preliminary and open one.

\section{List of references}

ARMSTRONG, D.M. 1983. What is a law of nature? Cambridge: Cambridge University Press.

AYER, A.J. 1998. What is law of nature? (In Curd, M. \& Cover, J.A., eds. Philosophy of science: the central issues. New York: Norton. p. 808-825.)

BARTH, K. 1964. Church dogmatics. Vol. 3(1). Edinburgh: Clark.

CLAYTON, P. 2008. Contemporary philosophical concepts of law and nature: the quest for broad explanatory consonance. (In Watts, F., ed. Creation. law and probability. Minneapolis: Fortress. p. 37-58.)

COBB, J.B. \& GRIFFIN, D.R. 1976. Process theology: an introductory exposition. Philadelphia: Westminster Press.

CUMIN, P. 2007. Robert Jenson and the Spirit of it all; or, You (sometimes) wonder where everything else went. Scottish journal of theology, 60(2):161-179. as an example of open theism in a very positive light in his article "Trinity, temporality, and open theism".

23 How this is possible is a discussion on its own and will require more space than this article allows. Gunton (2000:90) argues for example that Jenson remains "well short of committing" to pantheism in his theology. 
CURTIS, J.M. 2005. Trinity, time, and sacrament: Christ's eucharistic presence in the theology of Robert W. Jenson. Journal for Christian theological research, 10:21-38.

DOOYEWEERD, H. 1958. A new critique of theoretical thought. Amsterdam: Paris.

DORRIEN, G. 2008. The lure of necessity of process theology. Cross currents, 58(2):316-336.

GUNTON, C.E. 2000. Creation and mediation in the theology of Robert Jenson: an encounter and a convergence. (In Gunton, C.E., ed. Trinity, time, and church: a response to the theology of Robert W. Jenson. Grand Rapids: Eerdmans. p. 80-93.)

HARRISON, P. 2008. The development of the concept of the laws of nature. (In Watts, F., ed. Creation: law and probability. Minneapolis: Fortress. p. 1336.)

HASKER, W. 2005. "The end of human life": Buddhist, process, and open theist perspectives. Journal of Chinese philosophy, 32(2):183-195.

HUME, D. 1902. Enquiries concerning the human understanding and concerning the principles of morals. Oxford: Clarendon.

JENSON, R.W. 1963. Alpha and omega: a study in the theology of Karl Barth. New York: Thomas Nelson.

JENSON, R.W. 1969. God after God: the God of the past and the God of the future, seen in the work of Karl Barth. Indianapolis: Bobs-Merrill.

JENSON, R.W. 1997. Systematic theology. Vol. 1: The Triune God. Oxford: Oxford University Press.

JENSON, R.W. 1999. Systematic Theology. Vol. 2: The works of God. Oxford: Oxford University Press.

JENSON, R.W. 2006. God's time, our time. Christian century, 2: 31-35.

KLAPWIJK, J. 2008. Purpose in the living world? Creation and emergent evolution. Cambridge: Cambridge University Press.

MATTES, M.C. 2000. An analysis and assessment of Robert Jenson's systematic theology. Lutheran quarterly, 14(4): 463-494.

PANNENBERG, W. 2000. A Trinitarian synthesis. First things, 103:49-53.

PANNENBERG, W. 2007. God of the philosophers. First things, 174:31-34.

POLKINGHORNE, J. 2008. Afterword: some further reflections. (In Watts, F., ed. Creation: law and probability. Minneapolis: Fortress. p. 189-192.)

RICE, R. 2007. Trinity, temporality, and open theism. Philosophia: philosophical quarterly of Israel, 35(3-4):321-328.

STRAUSS, D.F.M. 2009. Philosophy: discipline of the disciplines. Grand Rapids: Paideia.

VERHOEF, A.H. 2011a. Timelessness, trinity and temporality. Acta academica, 43(2):82-112.

VERHOEF, A.H. 2011b. Trinity, time and ecumenism in Robert Jenson's theology. Dutch reformed theological journal, 52(1-2): 247-256.

WARD, K. 2008a. Divine action: examining God's role in an open and emergent universe. West Conshohocken: Templeton Foundation Press.

WARD, K. 2008b. The big questions in science and religion. West Conshohocken: Templeton Foundation Press.

WATTS, F. 2008. Concepts of law and probability in theology and science. (In Watts, F., ed. Creation: law and probability. Minneapolis: Fortress. p. 112.) 


\section{Key concepts:}

creation order

Jenson, Robert W.

process philosophy

Trinitarian theology

Kernbegrippe:

Jenson, Robert W.

prosesfilosofie

skeppingsorde

Trinitariese teologie 
